\title{
Relationship Between Business Ethics and Corporate Social Responsibility of Listed Manufacturing Companies in Nigeria
}

\author{
Mary Shadrach OMOFOWA ${ }^{1}$, Shadrach OMOFOWA ${ }^{2}$, Chijioke NWACHUKWU ${ }^{3}$, \\ XuyenThi My NGUYEN ${ }^{4}$ \\ \{maryshadrach7@gmail.com ${ }^{1}$, shadrachomofowa@gmail.com² ${ }^{2}$, cesogwa@yahoo.com³ \\ xuyen.ntm@vlu.edu.vn $\left.{ }^{4}\right\}$
}

\begin{abstract}
${ }^{1}$ Department of Business Administration, University of Benin, Nigeria., ${ }^{2}$ Global Business School, Nigeria., ${ }^{3}$ Horizons University Paris and Department of Financial Technologies, South Ural State University Chelyabinsk, Russia., ${ }^{4}$ Corresponding Author. Lecturer, Faculty of Business Administration, Van Lang University, Vietnam
\end{abstract}

\begin{abstract}
This study examines the impact of business ethics on corporate social responsibility. We has employed surveys conducted on 50 manufacturing companies listed on the Nigerian Stock Exchange. 236 employees participated in the study. The regression results suggest that ethical code, corporate image, ethical leadership and brand equity influences corporate social responsibility of sample manufacturing firms. Our results lend support to the role business ethics play in fostering corporate social responsibility in the emerging country context. Drawing on the stakeholder perspective, the study addresses business ethics and corporate social responsibility, thus adding to strategic management literature, especially in Nigeria. This study informs managers and stakeholders in the manufacturing sector on the importance of creating an enabling environment that encourages corporate social responsibility.
\end{abstract}

Keywords: brand equity, corporate image, corporate social responsibility, ethical code, ethical leadership. JEL:M0, M10, M14

\section{Introduction}

The efficient utilisation of resources, the creation of human capital, and the implementation of appropriate management strategies are all factors in modern businesses' development and growth. Economic advantage is achieved by aggressive behaviour and the effective use of financial tools available to businesses (Nwachukwu, Žufan\&Chládková, 2020). As such, business ethics and corporate social responsibility can foster competitive edge and sustainability of the corporation and as well add value to society. Society has questioned the existence of corporations because of the negative corporate behaviours of some of them (Davis, 1999). Besides, the notion that corporate activity is all about profit-making has become a major concern to stakeholders (Friedman, 1970, Jensen 2001). In developing countries, corporations have paid less attention to the ethical and social expectation of society. Business ethics focus on ethical principles and the moral conduct of corporations. It is a code of values and principles that governs corporate actions towards what is regarded as right or wrong. Firms need guidelines, rules, and procedures to support their strategic initiatives 
(Wanner, 2014). Business ethics provide a guideline on how a business should act in the face of ethical dilemmas and controversial situation. Corporate social responsibility suggests balancing social, environmental and economic practices by acting ethically to sustain stakeholder satisfaction (Agyemang\&Ansong, 2017; Feng, Wang \&Kreuze, 2017; Pinto \&Allui, 2020). Firms can use CSR strategy to enhance their reputation, brand, customer loyalty and improve business performance (Soewarno, Tjahjadi\&Fitriyah, 2021; Zahari et al., 2020). The 2002 awful event on corporate scandals involving Enron, Tyco, Worldcom, and their accounting firm Authur Anderson received global concern. Unethical practice, manipulations and malpractices led to the death of these companies. These scandals impelled business and stakeholder to scrutinize company ethics and operation, making the ordinary investors to understand the very essence of ethical behaviour in organization framework. Unethical behaviour or a lack of corporate social responsibility will destroy a company's image and make it less attractive to relevant stakeholders (Daft, 2001). While recent research has focused on business ethics and corporate social responsibility (e.g., Falola et al., 2018; Feng, Wang \&Kreuze, 2017; Hebe, 2018), a study of the business literature shows that there are very few studies in the field of business ethics and corporate social responsibility in terms of their importance to business operations and stakeholders. Prior studies examined ethical leadership and employees' creativity (Hebe, 2018), ethics in corporate social responsibility (Singh \& Singh 2013), corporate standard and corporation moral responsibility (Abun, 2015), corporate image and customers behavioural outcome (Falola et al., 2018; Adda, Azigwe\&Awuni, 2016; Milenkovska, Petrovsja\&Stoikovsk, 2019) and performance (Agyemang\&Ansong, 2017; Lee, 2020; Porter \& Kramer, 2007; Miller, Eden \& Li, 2017). Most of these studies were not done in developing economies contexts such as Nigeria. In Nigeria, very few indigenous companies have a life span of 50 years due to very weak institutions which hardly carry out reforms. There is a gap in the literature in terms of understanding how ethical norms, values code of conduct and ethical practice influence corporate social responsibility. This study attempt to narrow this knowledge gap. The aim of this paper is to investigate the relationship between business ethics aspects (ethical code, corporate reputation, ethical leadership, and brand equity) and manufacturing firms' corporate social responsibility initiatives in Nigeria. We contribute to the theoretical understanding of ethical norms, values, code of conduct and ethical practice in organisations, by examining the effect of major components of business ethics on corporate social responsibility of manufacturing firms. Since ethical norms, values practices of ethical principles in developing nations differ from the developed world, the present study is relevant.

\section{Literature review}

The stakeholder theory encompasses the study. Stakeholders continue with the presumption that principles are clearly a part of doing business, according to Freeman, Wicks, and Parmar (2004). Stakeholder theory suggests that companies are obligated to show concern for the environment and social problems of stakeholders (Famiyeh, 2017; Freeman \& Reed, 1983; Mahrani\&Soewarno, 2018). The stakeholder principle of corporate social responsibility is based on economic principles and asserts that, rather than its stockholders, a company is socially liable to look after the interests of a broader number of stakeholders, including owners, vendors' workers, and the environment (Rodin, 2005). We argue that the means of meeting the expectations and needs of stakeholders is by implementing ethical behaviour. A 
socially responsible corporation must consider the impact of its decision on a wider range of stakeholders. Innovative strategies can enable organizations to meet and surpass the expectations of divergent stakeholder and enhance competitive advantages (Vu, 2020). A corporation business ethics goes beyond trust and complying with the laws but include several other important stakeholders whose lives can be affected by the corporation decisions. Ebitu and Beredugo (2015) study the role of codes of ethics in leading the service industry's corporate success and enforcement in Calabar, Nigeria. The produced data revealed that successful organisational success was built on a code of ethics, and the degree of enforcement was strong, according to the Chi-square review. Ethical behaviour contributes to employees' performance and improves social and corporate performance (Saeed, Shekeel\&Lodhi, 2013) and Adda, Azigwe and Awuni (2016) observe that ethical code is important for customer and employee relations as well as business growth. Razaq et al. (2013) examine the effect of ethical principles and codes on corporate social responsibility in Pakistan's public sector. The findings suggest that ethical principles and codes have a positive impact on corporate social responsibility. In other commercial affairs, good corporate ethics act on data ethically. In the minds of the public, a company's reputation is described as an overall appraisal of the company (Aydin\&Ozer, 2005). Customers' thoughts, emotions, and perceptions shape a company's image. Al Mubarak, Ben Hamed, and Al Mubarak (2019) investigate the effect of corporate social responsibility on company profile.Customers saw corporate social responsibility as the most important factor when dealing with businesses, according to the findings. When businesses engage in those practises, their public profile improves. In the banking sector, Vazifehdust, Mojoudi, and Jalalian (2014) examine the impact of corporate social responsibility on business reputation, customer retention, and loyalty. They discovered that corporate social responsibility improves a company's reputation.Ethical leadership entails modelling normatively appropriate behaviour through personal decisions and interpersonal relationships, as well as promoting it through two-way contact, encouragement, and decisionmaking (Trevino, Brown \& Hartman, 2003). Externalities synonymous with ethical leadership include trust and loyalty (Berrone, Sureroca\&Tribo, 2007).In corporate social responsibility, ethical leadership refers to how ethical leaders, or workers, perceive their responsibility or obligation to make choices that protect and encourage the health and well-being of stakeholders and community. Financial crises, economic poverty, climatic change, societal insensitivity, workforce ethnic and sexual harassment, and periods of corporate financial irregularities all need ethically sensitive officials (Bello, 2012). Training on ethical leadership conduct, according to Walumbwa et al. (2011), encourages organizational business practices and relationships.Piccolo et al. (2010) examine the importance of mission autonomy and task relevance in the relationship between ethical leadership and organizational success. The findings show that ethical leadership increases mission significance, which improves organizational efficiency. Corporate social responsibility has a direct effect on a company's brand equity and profitability. (Lai, Chiu, Yang \& Pai, 2015). Tuan (2014) observes that ethical leadership and brand equity are important predictors of legal, economic and moral responsibility in Vietnam. Based on the literature review the following research hypotheses are formulated.

H1. There is significant relationship between the ethical code and corporate social responsibility.

H2. There is significant relationship between corporate image and corporate social responsibility.

H3. There is significant relationship between ethical leadership and corporate social responsibility. 
H4. There is significant relationship between brand equity and corporate social responsibility.

\section{Methodology}

The study applied a cross-sectional research approach. Primary data has been obtained from fifty (50) listed manufacturing companies that have been in operation in Nigeria since 1980 in (5) subsectors. Food-beverage-tobacco, breweries, chemical and paint, consumer and domestic goods, conglomerates-building materials, and pharmaceuticals are among these subsectors. The facts that these are the most environmentally visible and responsive subsectors of the manufacturing industry influenced the selection of these subsectors. Moreover, the manufacturing industry was selected because they are known to engage in corporate social responsibility in their locality. We selected employees who had more work experience for at least $15 y$ rs to ensure that participants had been exposed to a considerable period of corporate social responsibility and had observed the model of business operation of these companies to ascertain their compliance with ethical and best practices. The total population of the study is 576 comprising of top management employees who have spent $15 \mathrm{yrs}$ and above in these various manufacturing companies. The sample size of the study was determined by the use of the TARO Yamane formula.

$$
\mathrm{n}=\mathrm{N} / 1+\mathrm{N}(\mathrm{e})^{2}
$$

Where: $\mathrm{n}=$ sample size, $\mathrm{N}=$ population of study and $\mathrm{e}=$ error margin $5 \%$. Thus, $\mathrm{n}=576$ / $\left(1+576(0.05)^{2}\right.$ and the sample size of the study is 236 .

236 questionnaires were sent to workers at different industrial firms who had worked for 15 years or more. The distribution of the copies of the questionnaires was done on equal representation of these manufacturing companies to be able to capture all the various dimension of business ethics and corporate social responsibility. Only 200 questionnaires were found suitable for our analysis. Questions were developed using the five-point Likert scale ranging from "strongly disagree" to "strongly agree". The Ethics Position questionnaires (EPQ) was developed by Forsyth to measure ethical ideologies, codes and morals conduct held by employees. However, the ethics position Questionnaires was re-modified for appropriateness of the independent variable. It has a high degree of internal accuracy (Forsyth, 1980; Schlenker\& Forsyth) and has been included in a number of trials, including Singhapakdi and Vitell (1994) and Rawwas, Patzer, and Klasseh (1994). (1995). The 5-item leadership at work (ELW) questionnaire created by Kalshoven, Den Hartog, and De Hough was used to test ethical leadership (2011). Fairness, honesty, legal advice, task clarity, and respect for sustainability are among the factors measured in the questionnaires.A five-item corporate social responsibility scale was used to test attitudes about stakeholders' support and beneficial management activities (Valentine \& Fleischman, 2008; Valentine \&Godkin, 2009).Data were analyzed using OLS regression, canonical correlation analysis techniques and descriptive statistic. To certify the regression analysis fit before generalisation, the Jacque Bera normality test, correlation, and OLS regression analysis, as well as the post regression diagnostic test (PRDT) were used. The VIF test, a test for heteroskedasticity, and the Ramsey regression specification-error test for omitted variables are among the tests (Ramsey Reset). The mathematical package for data processing in this thesis was STATA version 13.0.

Thus, the model Specification is established as follows:

$\mathrm{CSRA}=\alpha 0+\beta 1 \mathrm{ECOD}+\beta 2 \mathrm{COPI}+\beta 3 \mathrm{ELSH}+\beta 4 \mathrm{BREQ}+\mathrm{Ui}$ 


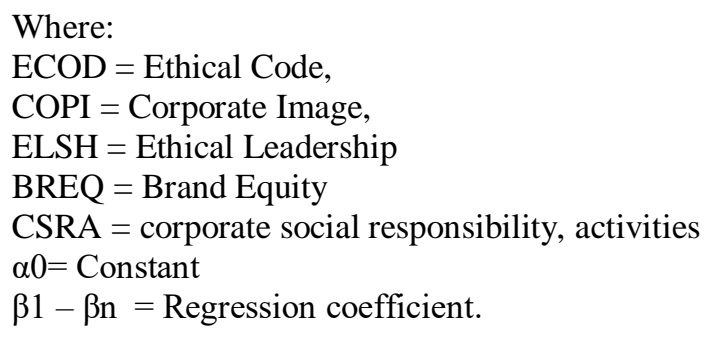

\section{Results}

The Cronbach alpha statistic index test was used to determine reliability, and a pilot test was conducted with 20 copies of the questionnaires distributed at random to workers of the manufacturing firms. The pilot test reveals that the questionnaire is relevant and reliable because the Cronbach's alpha for business ethics (0.78) and CSR (0.87) is higher than the minimum threshold of 0.70 . Using STATA version 13.0 programme, data was obtained and the questionnaire's reliability was calculated. Participants' answers were handled with anonymity to avoid traditional process prejudice (Conway \& Lance, 2010; Podsakoffet al., 2003), which minimized apprehension. Further respondents were informed that the independent variable (ethical codes, corporate image, ethical leadership and brand equity) is not linked to the dependent variable (corporate social responsibility). Since there is no heteroscedasticity problem, the heteroscedasticity test (table 3) assumes that the difference between the dependent and independent variables is homoscedastic. The model is free of unequal variance at 1.27(0.2631), implying that the regression findings are sufficient to evaluate the hypotheses. The mean VIF value in the variance inflation factor test is 2.67 , which is smaller than the reference value of 5. (Ringle et al., 2015). This means that multicollinearity is not present. The probability value of 0.3479 derived from the Ramsey regression equation definition error test indicates that there are no omitted variables in the formula.

\begin{tabular}{c|ccccr}
\multicolumn{5}{c}{ Table 1. Descriptive statistics } & \\
variable | & mean & p50 & max & min & $N$ \\
ecod | & 4.205 & 4 & 5 & 2 & 200 \\
copI | & 4.245 & 4 & 5 & 2 & 200 \\
elsh | & 4.325 & 4 & 5 & 2 & 200 \\
breq | & 4.265 & 4 & 5 & 2 & 200 \\
csra | & 4.24 & 4 & 5 & 2 & 200
\end{tabular}


Table 2. Correlation results

\begin{tabular}{l|ccccc} 
& ecod & copi & elsh & breq & csra \\
ecod | 1.0000 & & & & \\
copi | 0.7549 & 1.0000 & & & \\
elsh | 0.7089 & 0.7242 & 1.0000 & & \\
breq | 0.7206 & 0.4894 & 0.5716 & 1.0000 & \\
csra | 0.7313 & 0.7368 & 0.8041 & 0.5258 & 1.0000
\end{tabular}
below

The following hypotheses were tested using OLS Multiple Regression $n$ the Table 1

Table 3: OLS Regression result of business ethics and corporate social responsibility

\begin{tabular}{|l|l|l|l|}
\hline Variables & B & T & P $/$ t/ $/$ \\
\hline Ethical Code & 0.2858952 & 3.86 & 0.000 \\
\hline Corporate Image & 0.1360846 & 1.98 & 0.029 \\
\hline Ethical Leadership & 0.4813349 & 7.92 & 0.000 \\
\hline Brand Equity & 0.1099185 & 1.98 & 0.031 \\
\hline Cons. & 0.0959061 & 0.49 & 0.628 \\
\hline R-squared & 0.7330 & & \\
\hline Adj. R-squared: & 0.7261 & \\
\hline F & 106.52 & \\
\hline Prob.>F. & 0.0000 & \\
\hline Post Regression test: & $1.25(0.2631)$ \\
\hline Heteroskedasticity & 0.3479 & \\
\hline Ramson RESET test & 2.67 \\
\hline Mean VIF
\end{tabular}

Source: Own (2020)

The descriptive features of the data collection used in the study as seen in Table 1. The constructs have a higher value of 5, meaning that the respondents are strongly in agreement with all of the questions posed at some point, while the constructs have a lower limit of 2, indicating that the respondent disagrees with some query. The sample size is 200 respondents, according to the descriptive statistics. Based on the average findings, we can deduce that participants agree with the following statements: ethical code (4.21), corporate reputation (4.25), ethical leadership (4.33), and market equity (4.33). (4.26).Regression result in table 3 reveals that ethical code, corporate image, ethical leadership and brand equity $\mathrm{R}^{2}=(.733)$ jointly accounts for $73.3 \%$ variation in corporate social responsibility in manufacturing companies in south-south Nigeria. Other variables not included in the present study explain $26.7 \%$. variation in corporate social responsibility in manufacturing companies. The standard coefficients (beta) were used to evaluate the strength of ethical code corporate image, ethical leadership and brand equity. The regression results in table $3,(t=3.86, \beta=0.286, p<.05)$ supports $\boldsymbol{H I}$ there is a significant relationship between ethical codes and corporate social responsibility. This result is consistent with other related studies (e.g., Ebitu\&Beredugo, 2015; 
Razaq et al., 2013; Obara\&Paelttie, 2017; Preuss \& Brown, 2012) that concluded ethical codes fosters positive behaviour, integrity, and resourcefulness. The mission statements communicate the strategic posture of firms to their stakeholders (Nimwegen, Bollen, Hassink\&Thijssens, 2008). Strategically, a mission statement must communicate a firm's ethical codes and values. The removal of ethical code and values can lead to failure and collapse of firms. We infer that organization that is committed to implementing ethical codes and values tends to engage more in corporate social responsibility. $\boldsymbol{H} 2(\mathrm{t}=1.98 . \beta=0.136, p<$ $.05)$ there is a significant relationship between corporate image and corporate social responsibility is affirmed. This result provides support to the notion that corporate image influences corporate social responsibility (Al Mubarak, Ben Hamed\&Al Mubarak, 2019; Vazifehdust, Mojoudi\&Jalalian, 2014). $\boldsymbol{H 3}(\mathrm{t}=7.92, \beta=.481 p<.05)$ there is a significant relationship between ethical leadership and corporate social responsibility is supported. This result aligns with related studies that ethical leadership strengthen moral responsibility and corporate social responsibility (e.g. Tuan, 2014; Walumbwa et al., 2011, Piccolo et al., 2010). Strategic leaders need to conduct business ethically to ensure business sustainability (Nwachukwu \& Vu, 2020). Arguably, ethical leaders that are committed to their job may experience a high quality of relationship with various stakeholders. Our result also supports $\boldsymbol{H} 4(\mathrm{t}=1.98, \beta=.109, p<.05)$ there is a significant relationship between brand equity and corporate social responsibility. This finding agrees with extant literature (e.g., Lai, Chiu, Yang \&Pai, 2015; Saeednia\&Sohani, 2013; Ebitu\&Beredugo, 2015) that implementing brand equity helps to identify and deal with ethical misconduct, an initiative to support quality corporate social responsibility. All the predicted hypotheses are supported. Given the scarcity of study on management practises in Nigeria's manufacturing industry, (Nwagu, 2019), particularly business ethics and corporate social responsibility, the present study contributes to strategic management and business policy literature. By recognizing the positive impact of ethical codes, corporate image, ethical leadership and brand equity, organizations can gain legitimacy. Developing and executing robust policies (e.g. human resources) can promote positive organisational outcome, strategic performance (Vu \& Nwachukwu, 2020). In this context, strengthening, elaborating, and constantly improving policies framework in the sphere of ethical codes, leadership quality, brand equity and corporate image can foster corporate social responsibility.

\section{Conclusion}

Firms' resources and managerial processes can foster an ethical business environment. This study enriches our understanding of ethical code, ethical leadership, corporate image, brand equity and corporate social responsibility of manufacturing companies, in south-south Nigeria. Our result suggests that corporate social responsibility is influenced by ethical codes, corporate image, ethical leadership and brand equity. We observed that ethical leadership has the greatest effect on CSR compare to ethical codes, brand equity and company image. It becomes imperative for companies to set their priorities rights and give attention to host community stakeholders in terms of their corporate social responsibility activities. These findings are highly critical for the competitiveness and efficiency of Nigerian manufacturing companies. Improving and engaging in corporate social responsibility will lead to positive organizational outcomes. This study informs managers and stakeholders in the manufacturing sector on the importance of creating an enabling environment that encourages corporate social 
responsibility. Doing this would promote a harmonious relationship between the companies and their stakeholders. Given the stated discussion, finding and conclusion, the author proposes the following suggestions that could assist managers to implement business ethics and enhance corporate social responsibilities activities of organizations.

- Ethical code should be used to foster positive behaviour, attitude and preservation of corporate culture. This could help to prevent failures and collapse of intended or established social responsibility activities.

- Manufacturing companies should give attention to their corporate image it helps to speak on their behalf.

- Manufacturing companies must ensure that managers in the helm of affairs possess ethical leadership skills this would help in strengthening moral responsibility, commitment and loyalty of managers in executing corporate social responsibility activities.

- Manufacturing companies should pay attention to their brand equity since they serve as a non-paid form of advertisement.

The current thesis has some flaws that should be addressed in future research. Our research centred on Nigeria's manufacturing industry. Then, to some extent, restrict the study's generalizability outside this sense. Patel, Kohtamäki, Parida, \&Wincent, 2015; Parida\&Ortquist, 2015) found that a single market analysis decreases the difficulty of multiple business surveys. More studies can be conducted in various sectors, with a large sample size, and across countries to get a better understanding of the phenomena.

\section{References}

[1] Abun, D. (2015). Moral standard and corporation moral responsibility. South American Journal of Management, 1(2), 1-15.

[2] Adda, G., Azigwe, J. B. \&Awuni, A. R. (2016). Business ethics and corporate social responsibility for business success and growth. European Journal of Business and Innovation Research, 4(6), 26-42.

[3] Agyemang, O. S., \&Ansong, A. (2017). Corporate social responsibility and firm performance of Ghanaian SMEs: Mediating Role of Access to Capital and Firm Reputation. Journal of Global Responsibility, 8(1), 47-62.

[4] Al Mubarak, Z., Ben Hamed, A.\&Al Mubarak, M. (2019). Impact of corporate social responsibility on bank's corporate image. Social Responsibility Journal, 15(5), 710-722.

[5] Aydin S \& Ozer, G. (2005). The analysis of antecedents of customers loyalty in the Turkish mobile telecommunication market. Europe Journal of marketing, 39(7), 910-925.

[6] Bello, S. M. (2012). Impact of ethical leadership on employees' job performance. International Journal of Business and Social Science, 3(11) 228-236.

[7] Berrone, P., Sureroca, J. \&Tribo, J. A. (2007). Corporate ethical identity as a determinant of firm performance. A test of the mediating role of stakeholder satisfaction. Journal of business ethics, 76(1), 35-53.

[8] Conway, J. M. \& Lance, C. E. (2010). What reviewers should expect from authors regarding common method bias in organizational research. Journal of Business and Psychology, 25(3), $325-334$

[9] Daft, R. (2001). Organization theory and design. Cincinnati, Ohio: South Western.

[10] Ebitu, E. T. \&Beredutgo, S. B. (2015). Business ethics and the performance of service firms in Calabar, Cross River, Nigeria. European Journal of Hospitality and Tourism Research, 3(2), 28-38.

[11] Falola, H. O, Adeniji, A. A, Adeyeye, J. O., Osibanjo, A. O, Igbinoba, E. E \&Salau, O. P. (2018) Corporate image and customers behavioral outcomes in the ICT inclined hospitality 
industry in Nigeria. Intentional Journal of Mechanical Engineering and Technology, 9(13), 854-864.

[12] Famiyeh, S. (2017). Corporate social responsibility and firm's performance: empirical evidence. Social Responsibility Journal, 13(2), 390-406.

[13] Feng, M., Wang, X., \&Kreuze, J. G. (2017). Corporate social responsibility and firm financial performance Comparison analyses across industries and CSR categories. American Journal of Business,32(3/4), 106-133.

[14] Forsyth, D. R. (1980). A Taxonomy of ethical ideologies. Journal of Personality and Social Psychology, 39(1), 175-184.

[15] Freeman, R. E. \& Reed, D. L. (1983). Stockholders and stakeholders: a new perspective on corporate governance. California Management Review, 25(3), 88-106.

[16] Freeman, R. E., Wicks, A. C. \& Parmar, B. (2004). Stakeholder Theory and The Corporate Objective Revisited. Organization Science, 15(3), 364-369.

[17] Friedman, M. (1970). The social responsibility of business is to increase its profits. The New York Times Magazine 32, 122-126.

[18] Hebe, K. E. (2018). The effect of ethical leadership on employees creativity. International Journal of Economics and Management Science, 7(5), 1-13.

[19] Jensen, M. C. (2001). Value maximization, stakeholder theory, and the corporate objective function. Journal of Applied Corporate Finance, 14(3), 8-21.

[20] Kalshoven, K., Den Hartog, D. N. \& De Hough, A. H. (2011). Ethical leadership at work questionnaire (ELW); development and validation of multidimensional measures. The Leadership Quarterly, 22(1), 51-69.

[21] Lai, C. S., Chiu, C. J., Yang, C. F. \& Pai, D. C. (2015). The effects of corporate social responsibility on brand performance. The mediating effect of industrial brand equity and corporate reputation. Journal of Business Ethics, 14(4), 457-469.

[22] Lee, J. W. (2020). CSR Impact on the Firm Market Value: Evidence from Tour and Travel Companies Listed on Chinese Stock Market. Journal of Asian Finance, Economics and Business, 7(7), 159-167.

[23] Mahrani, M., \&Soewarno, N. (2018). The effect of good corporate governance mechanism and corporate social responsibility on financial performance with earnings management as mediating variable. Asian Journal of Accounting Research, 3(1), 41-60.

[24] Milenkovska, V., Petrovsja, J. \&Stoikovsk, A. (2019). Positive attitude towards business ethics and social responsibility for improving corporate image. UTMSJournal of economics, 10(1), $97-107$.

[25] Miller, S. R., Eden, L. \& Li, D. (2017). Corporate social responsibility and firm performance A dynamic approach. Journal of Business Ethics, 163(3), 619-636.

[26] Nimwegen, V. G., Bollen, H. L., Hassink, H. \&Thijssens, T. (2008). A stakeholder perspective on mission statements: An international empirical study. International Journal of Organizational Analysis, 16(1/2), 61-82.

[27] Nwachukwu, C. \& Vu, M. H. (2020). Strategic flexibility, strategic leadership and business sustainability nexus. International Journal of Business Environment, 11(2), 125-143.

[28] Nwachukwu, C., Žufan, P. \&Chládková, H. (2020). Employee commitment to strategy implementation and strategic performance: organisational policy as moderator. International Journal of Business Excellence, 20(3), 398-418.

[29] Nwagu, K. (2019). Impact of practices of corporate social responsibilities on the performance of Business in the context of contemporary Nigeria society. Texila International Journal of Management,Special edition, 1-15.

[30] Obara, L. J. \& Peattie, K. (2017). Bridging the great divide? making sense of the human right CSR, Relationship in UK multinational companies, Journals of World Business, 53(6), 781793

[31] Parida, V. \&Örtqvist, D. (2015). Interactive effects of network capability: ICT capability, and financial slack on technology-based small firm innovation performance. Journal of Small Business Management,53(S1), 278-298. 
[32] Patel, P. C., Kohtamäki, M., Parida, V. \&Wincent, J. (2015). Entrepreneurial orientation asexperimentation and firm performance: the enabling role of absorptive capacity. Strategic Management Journal, 36(11), 1739-1749.

[33] Piccolo, R. F., Greenaum, R., DenHartog, D. N. \& Folger, R. (2010). The relationship between ethical leadership and core job characteristics. Journal of Organizational Behaviour 31, 259 278.

[34] Pinto, L. \&Allui, A. (2020). Critical Drivers and Barriers of Corporate Social Responsibility in Saudi Arabia Organizations. Journal of Asian Finance, Economics and Business, 7(11), 259268.

[35] Podsakoff, P., MacKenzie, S., Lee, J. \& Podsakoff, N. (2003). Common method biases in behavioral research: a critical review of the literature and recommended remedies. Journal of Applied Psychology, 88(5), 879-903.

[36] Porter, M. E., \& Kramer, M. R. (2007). Strategy and Society: The Link Between Competitive Advantage and Corporate Social Responsibility. Harvard Business Review84, 78-92.

[37] Preuss, L \& Brown, D (2012). Business, policies on human rights. an analysis of their content and prevalence among FTST 100 firms. Journals of business ethics, 109(3), 2789-299.

[38] Rawwas, M. Y. A. \& Patzer, G. L. (1995). Consumer ethics in cross- cultural settings entrepreneurial implications. European Journal of marketing, 29(7), 62 -78.

[39] Razaq, S., Ahmad, M., Zahid, S., Razaq, W., Gul, R. \& Naeem, N. (2013). The impact of ethical values on the corporate social responsibility in public sector of Pakistan. European Journal of Business and Management,5(1), 44-50.

[40] Saeed, R., Shekeel, M. \& Lodhi, R. N. (2013). Ethical behaviour and employee performance in education section of Pakistan. Middle East Journal of Scientific Research, 18(4), 524-529.

[41] Saeednia, H. R. \&Sohani, Z. (2013). Investigation of effects of advertising on social responsibility reputation and value of brand equity of companies. Management Science Letters, 3(4), 1139-1144.

[42] Schlenker, B. R. \& Forsyth, D. R. (1977). On ethical of psychological research. Journal of Experimental Social Psychology, 13(4), 369-396.

[43] Singh, K. H. T. \& Singh, M. S. (2013). Ethic in corporate social responsibility. IOSR Journal of Business and Management, 9(2), 16-21.

[44] Singhapakdi, A. \& Vitell, S. J. (1994). A cross cultural study of moral philosophies ethical perception and judgments - a comparison of American and Thai marketer. International Marketing Review, 11(6), 65-78.

[45] Soewarno, N., Tjahjadi, B. \&Fitriyah, M. (2021). The Role of Corporate Social Responsibility on the Relationship of Competitive Pressure and Business Performance of Batik Industry in Central Java, Indonesia. Journal of Asian Finance, Economics and Business,8(1), 863-871.

[46] Trevino, L. K., Brown, M. \& Hartman, L. P. (2003). A qualitative investigation of perceived executive ethical leadership perception form inside and outside the executive suit. Human relations, 55(1), 5-37.

[47] Tuan, K. (2014). Corporate social responsibility leadership and brand equity in health care service. Social Responsibility Journal, 8(3), 347-362.

[48] Valentine, S \&Godkin, L. (2009). Ethics, social responsibility, and ethical reasoning in an education-based health science center: When doing good results in good employees. Journal of Leadership, Accountability and Ethics, 7(3), 1-17

[49] Valentine, S. \& Fleischman, H. (2008). Ethics programs, perceived corporate social responsibility and Job Satisfaction. Journal of Business Ethics, 77(2), 159-172.

[50] Vazifehdust, H., Mojoudi, A \&Jalalian, S (2014). The effect of corporate social responsibility on corporate image, customers satisfaction and loyalty in the banking industry (case study: Tehran Melli Bank). Paper presented at Conference of Development and innovation management in management empowerment, pp. 1-23.

[51] Vu, H. M. \& Nwachukwu, C. (2020). Human resources, financial resources and strategic performance: Organisational policy as moderator. Quality-Access to Success Journal, 21(175), $18-24$. 
[52] Vu, H. M. (2020). A review of dynamic capabilities, innovation capabilities, entrepreneurial capabilities and their consequences. Journal of Asian Finance, Economics and Business, 7(8), 485-494

[53] Walumbwa, F. O., Mayer, M. D., Wang, P., Wang, H., Workman, K., \& Christensen, A. L. (2011) Linking ethical leadership to employee performance. The role of leader-member exchange, self-efficacy, and organizational identification. Organizational Behavior and Human Decision Process, 155(2), 204-213

[54] Wanner, M. F. (2014). Implement strategy by strategic initiatives with effective program and change management. Paper presented at PMI® Global Congress 2014-EMEA, Dubai, United Arab Emirates. Newtown Square, PA: Project Management Institute.

[55] Zahari, A.R., Esa, E., Rajadurai, J., Azizan, N. A. \&MuhamasTmayez, P. A. (2020). The Effect of Corporate Social Responsibility Practices on Board Equity: An Examination of Malaysia's Top 100 Brands. Journal of Asian Finance, Economics and Business, 7(2), 271-280 